\title{
CATO THE ELDER ON HUMAN AND ANIMAL DISEASES AND MEDICINES FOR THEM - ACCORDING TO THE TREATISE ON AGRICULTURE
}

ABSTRACT: Cato the Elder was a great speaker, respected politician, military commander and writer. His treatise De agri cultura (On Agriculture) contains not only numerous passages on farm management, but also cooking recipes, religious principles, advice on how to obtain supplies, and very specific medical advice and medicinal recipes. Cato heals many different diseases of humans and quadrupeds (especially oxen). He knows how these medicines, various types of wines and cabbage dishes, should be concocted. His recipes are detailed and appear to indicate that the author knows them well. Cato does not neglect the religious and magical elements in his medical advice. Therefore, his treatise is an interesting source of Roman spells. First of all Cato's manual on agriculture is a significant testimony of Roman medicinal and veterinary knowledge of the time, but also of the importance of these issues for the elite of the Roman Republic.

KEY WORDS: Cato the Elder, disease, medicine, On Agriculture (De agri cultura)

The ancient Romans are considered primarily great warriors, as well as lawyers or citizens involved in the affairs of the Republic. This article, however, reminds us that the Roman virtue (virtus Romana) also connoted being a good house master, which included a fairly good knowledge of contemporary medical art: a good house master could cure his people and animals. Taking care of great affairs of the state was seen as 
parallel to care for home, and this in turn was associated, among others, with the knowledge of herbs and recipes for healing specifics.

The purpose of this paper is to determine the state of knowledge in in the field of folk medicine among the ancient Romans in Cato's times. The analysis of excerpts from his work will also show how important it was for a Roman citizen to know about an agricultural holding - also as far as the use of medicines for human and animal diseases. ${ }^{1}$

\section{CATO THE ELDER}

Marcus Porcius Cato, known as Cato the Elder and Cato the Censor (234 or $239 \mathrm{BC}-149 \mathrm{BC}$ ), was the great-grandfather of the famous Cato the Younger, who was a politician and statesman in the late Roman Republic and who opposed Julius Caesar. Cato the Younger was a descendant of the younger son (the epithet Salonianus) of Cato the Elder from his second marriage. ${ }^{2}$

Cato the Elder was a very important public figure, great speaker, respected politician, military commander and writer. He became famous as an enemy of Carthage, a conservative opponent of Hellenization (although he partially succumbed to Greek influence ${ }^{3}$ ) and a defender of the traditional virtues of republican Rome.

Cato came from an ancient plebeian family and as a homo novus followed the cursus honorum: he was a military tribune (214 or $210 \mathrm{BC}$; he became a soldier traditionally at the age of 17), a quaestor (204 BC; he accompanied Publius Cornelius Scipio as a quaestor in Sicily), a plebeian aedile (199 BC), a praetor (198 BC in Sardinia, where he became famous for his diligence in fighting extortion, bribery and usury), consul (195 BC; together with Flaccus) and finally censor (184 BC). He was so strict and severe a censor, fighting splendor and a decline in morals that he was nicknamed Censorinus. It must be remembered that he participated in many military campaigns, including the Second Punic War (he served at Capua and during the siege of Tarentum and contributed to the

1 Other authors who wrote on ancient Roman medical and veterinary issues include: Boscherini 1993: 730-740; Mezzabotta 2001: 137-152.

2 Cytowska, Szelest, Rychlewska 1996: 188.

3 Astin 1978: 157-181; Cytowska, Szelest, Rychlewska 1996: 203-204. 
decisive victory on the Metaurus), the campaign in Hispania (for which he was rewarded with the honor of a Roman triumph in 194 BC), and the Syrian War against Antiochus III the Great. In Rome he very often spoke in court and senate. ${ }^{4}$

Alongside his intense political involvement, Cato was also involved in literary work. He was the author of encyclopaedic and historiographic works. Cicero knew 150 political and judicial speeches by Cato. The titles of some of his works are well known, including Praecepta ad filium (or Ad Marcum filium; maxims addressed to his son), Carmen de moribus (a poem on morality), Commentarius de medicina (a commentary on medicine), Commentarii iuris civilis (commentaries on civil law), De re militari (on military matters), Apophthegmata vel dicta (Sayings), Origines (the history of the Italian towns, with special attention to Rome), Commentarius de historia (commentary on history), Epistulae (Letters). His manual on running a farm, De agri cultura (or De re rustica; On Agriculture $^{5}$ ), is his only work that survives completely. It has 162 short chapters and is the oldest surviving work of Latin prose, dated to about 160 BC. This farmer's notebook is a very valuable source of knowledge about Roman agriculture in the $3^{\text {rd }} / 2^{\text {nd }}$ century BC.

This work of Cato's is written in a "random fashion": it is a miscellaneous assortment of recommendations on husbandry and farm management. Its style is direct, but forceful and vigorous. The treatise $O n$ Agriculture is a very interesting depiction of rural life during the Roman Republic. It contains not only numerous passages on farm management, but also cooking recipes, religious principles, advice on how to obtain supplies and very specific medical advice, including recipes for medicines for people and animals, such as those used to move the bowels, remove colic, or treat bovine diseases, etc.

This agricultural treatise is a valuable testimony of the state of the "folk" medical and veterinary knowledge of the time of Cato and the importance of these issues among the Roman elite of those days. After all, Cato - a severe censor and pater familias vendax non emax (cf. Cato De agri cultura (Agr.) 2, 7: Patrem familias vendacem, non emacem esse oportet - "The master should have the selling habit, not the buying

$4 \quad$ Forde 1975; Astin 1978: 22-156.

$5 \quad$ Mikołajczyk 2009: 15. 
habit"; ed. G. Goetz, Lipsiae 1922; transl. W. D. Hooper and H. B. Ash, Loeb Classical Library edition, 1934) - has became a kind of personification of the ancient Roman virtues for conservative-republican groups. ${ }^{6}$

\section{MEDICINAL WINES}

\section{a. Wines made with the addition of Veratrum atrum}

Very numerous among Cato's medicinal specialties are recipes for wines. One of them gives a way of cultivating vines for a laxative wine, which works well on the bowels (ut alvum bonam faciat), by stimulating their work (alvum movebit - "it will move the bowels"). It is a wine with the addition of Veratrum atrum, elleborum (nowadays known as $\mathrm{Hel}$ leborus niger, black hellebore, a genus of flowering plants in the family Ranunculaceae):

secundum vindemiam, ubi vites ablaqueantur, quantum putabis ei rei satis esse vini, tot vites ablaqueato et signato. Earum radices circumsecato et purgato. Veratri atri radices contundito in pila, eas radices dato circum vitem et stercus vetus et cinerem veterem et duas partes terrae circumdato radices vitis. Terram insuper inicito. Hoc vinum seorsum legito.

After vintage, when the vines are trenched, expose the roots of as many vines as you think you will need for the purpose and mark them; isolate and clear the roots. Pound roots of black hellebore in the mortar, and apply around the vines. Cover the roots with old manure, old ashes, and two parts of earth, and cover the whole with earth. Gather these grapes separately (Cato Agr. 114, 1-2).

Cato also adds a way of storing this wine, dosage and way of drinking: "if you wish to keep the wine for some time as a laxative, do not mix it with the other wine. Take a cyathus [cyathus $=0,0451$ l] of this wine, dilute it with water, and drink it before dinner" (Si voles servare in vetustatem ad alvum movendam, servato, ne conmisceas cum cetero vino.

$6 \quad$ Mikołajczyk 2009: 11. 
De eo vino cyatum sumito et misceto aqua et bibito ante cenam - Cato Agr. 114, 2).

The next section also discusses wine produced using the Veratrum atrum, giving the following two recipes. The first is shorter and describes the use of the black hellebore during the production of the wine: "Throw in a handful of black hellebore to the amphora of must, and when the fermentation is complete, remove the hellebore from the wine; save this wine for a laxative" (In vinum mustum veratri atri manipulum coicito in amphoram. Ubi satis efferverit, de vino manipulum eicito. Id vinum servato ad alvum movendam - Cato Agr. 115, 1). The second recipe refers again to the cultivation of the vines: "When the vines are trenched, mark with red chalk so that you will not mix with the rest of the wine; place three bundles of black hellebore around the roots and cover with earth. Keep the yield from these vines separate during the vintage" (Vites cum ablaqueabuntur, signato rubrica, ne admisceas cum cetero vino. Tris fasciculos veratri atri circumponito circum radices et terram insuper inicito. Per vindemiam de iis vitibus quod delegeris, seorsum servato - Cato Agr. 115, 2). The author does not specify whether to use the rhizomes or the stalks of the Veratrum. The dosage and the way of drinking differ slightly than those of the earlier one: "Put a cyathus into another drink; it will move the bowels and the next day give a thorough purging without danger" (Alvum movebit et postridie perpurgabit sine periculo - ibidem).

\section{b. Myrtle wine}

Cato also describes a medicinal myrtle wine (vinum murteum) made from the berry of the myrtle (murta nigra). It is a remedy for stomach indigestion, for pain in the side, and for colic (id est ad alvum crudam et ad lateris dolorem et ad coeliacum - cf. Cato Agr. 125, 1): "Dry out black myrtle in the shade, and when dried keep it until vintage. Macerate a half-modius [modius $=8,751$ l] of myrtle into an urna [urna $=13,131$ ] of must and seal it. When the must has ceased to ferment remove the myrtle" (Murtam nigram arfacito in umbra. Ubi iam passa erit, servato ad vindemiam, in urnam musti contundito murtae semodium, id oblinito. Ubi desiverit fervere mustum, murtam eximito - ibidem; cf. Colum. De re rustica XII 38, 1-6). 


\section{c. Pomegranate wines}

Wine with the addition of fruits or flowers of the pomegranate (malum Punicum) has medicinal properties, according to Cato. The first wine is a remedy for the gripes, loose bowels, tapeworms and stomach-worms (ad tormina, et si alvus non consistet, et si taeniae et lumbrici molesti erunt). Cato recommends: "Take 30 acid pomegranates, crush, place in a jar with 3 congii [ congius $=3,281$ ] of strong black wine, and seal the vessel. Thirty days later open and use. Drink a hemina [hemina $=0,27$ 1] before eating" ( $X X X$ mala Punica acerba sumito, contundito, indito in urceum et vini nigri austeri congios III. Vas oblinito. Post dies XXX aperito et utito; ieiunus heminam bibito - Cato Agr. 126, 1). The second wine is an aid for dyspepsia and strangury (ad dyspepsiam et stranguriam mederi). The roots of fennel and pomegranate blossoms are taken during flowering of the trees: "place 3 minae [mina $=432 \mathrm{~g}$ ] of them in an amphora. Add one quadrantal [quadrantal = 26, 261 1] of old wine and a mina of clean crushed root of fennel; seal the vessel and thirty days later open and use" (tris minas in amphoram infundito, vini $Q$. I veteris addito et feniculi radicem puram contusam minam. Oblinito amphoram et post dies XXX aperito et utito - Cato Agr. 127, 1). This wine for digestion and urination can be drunk in any quantity: "You may drink this as freely as you wish without risk, when you wish to digest your food and to urinate" (Ubi voles cibum concoquere et lotium facere, hinc bibito quantum voles sine periculo - ibidem).

The same wine clears out tapeworms and stomach-worms (idem vinum taenias perpurgat et lumbricos, si sic concinnes). In this case, the author recommends refraining from eating in the evening on the first day (incenatum iubeto esse), and macerating 1 drachm [ drachma $=432 \mathrm{~g}]$ of pulverized incense, $1 \mathrm{drachm}$ of boiled honey, and a sextarius [sextarius $=0,54$ 1] of wine of wild marjoram the following morning (turis drachmam unam conterito et mel coctum drachmam unam et vini sextarium origaniti). It must be administered before eating (dato ieiuno). Cato prescribes a triobolus and a hemina for a child, according to age (puero pro aetate triobolium et vini heminam). Finally, the patient should climb onto a pile (supra pilam inscendat) and jump off ten times (decies) (or jump ten times on top of it - saliat) and walk around (deambulet - cf. Cato Agr. 127, 1-2). 


\section{d. Juniper wines}

There are two recipes for juniper wine in Cato's treatise. The text of the first recipe is a little damaged, but it is known that the author recommends using this wine for trouble with urination (si lotium difficilius transibit). First, the juniper or capreida should be macerated. The name of the second plant is not uniquely given by the manuscripts: capreidam or capidam. This plant is mentioned only in this passage and cannot be identified. Subsequently Cato recommends: "add a pound [libra = $379 \mathrm{~g}$ ] of it, and boil in 2 congii of old wine in a copper or lead vessel. After it cools, pour into a bottle. Take a cyathus in the morning before eating (ieiunus); it will prove beneficial" (libram indito, in duobus congiis vini veteris in vase aheneo vel in plumbeo defervefacito. Ubi refrixerit, in lagonam indito. Id mane ieiunus sumito cyatum; proderit - Cato Agr. 122, 1).

The second recipe is a formula for a wine used in treating gout (or sciatica, ischias, lumbago - ad isciacos ${ }^{7}$ ). This wine is made from juniper branches and boiled with old wine: "Cut into small chips a piece of juniper wood a half-foot [pes $=29,6 \mathrm{~cm}$ ] thick, boil with a congius of old wine, and after it cools pour into a bottle" (De iunipiro materiem semipedem crassam concidito minutim. Eam infervefacito cum congio vini veteris. Ubi refrixerit, in lagonam confundito). It should be a morning drink: "Take a cyathus in the morning before eating" (id utito cyatum mane ieiunus). Finally, Cato says again: proderit - "it will prove beneficial" (Cato Agr. 123, 1).

\section{MEDICAL PROPERTIES OF CABBAGE}

Cabbage (brassica) occupies a very special place among the medicines recommended by Cato. It is a vegetable surpassing all others (omnibus holeribus antistat - Cato Agr. 156, 1). Cato describes it in three long chapters. This fact may, according to some researchers, raise doubts about the authenticity (total or partial) of this fragment. ${ }^{8}$

\footnotetext{
$7 \quad$ Boscherini 1970: 106.

8 De Saint-Denis 1980: 838-849; Pitkäranta 1987: 31-45.
} 
Nevertheless, it is worth to present the advantages of cabbage according to Cato's treatise. Cabbage has many varietes and all are medicinal. First Cato discusses three varietes, levis, apiacon and the most effective lenis:

Omnia ad salutem temperat conmutatque sese semper cum calore, arida simul et umida et dulcis et amara et acris. Sed quae vocantur septem bona in conmixtura, natura omnia haec habet brassica. Nunc uti cognoscas naturam earum, prima est levis quae nominatur; ea est grandis, latis foliis, caule magno, validam habet naturam et vim magnam habet. Altera est crispa, apiacon vocatur; haec est natura et aspectu bona, ad curationem validior quam quae supra scripta est. Et item est tertia, quae lenis vocatur, minutis caulibus, tenera, et acerrima omnium est istarum, tenui suco vehementissima. Et primum scito, de omnibus brassicis nulla est illius modi medicamento.

it has all the virtues necessary for health, and constantly changes its nature along with the heat, being moist and dry, sweet, bitter, and acid. The cabbage has naturally all the virtues of the so-called «Seven Blessings» mixture. To give, then, the several varieties: the first is the so-called smooth; it is large, with broad leaves and thick stem; it is hardy and has great potency. The second is the curly variety, called «parsley cabbage»; it has a good nature and appearance, and has stronger medicinal properties than the above-mentioned variety. So also has the third, the mild, with small stalk, tender, and the most pungent of all; and its juice, though scanty, has the most powerful effect. No other variety of cabbage approaches it in medicinal value (Cato Agr. 157, 1-2).

Then Cato describes wild cabbage, brassica erratica, a very good remedy for various diseases (cf. Cato Agr. 157, 12-16). Cato writes that Pythagoras knew the medicinal value of cabbage (cf. Cato Agr. 157, 1: brassica Pythagorea; cf. Plin. Nat. XX 789).

Cabbage may be eaten either cooked or raw with vinegar (eam esto vel coctam vel crudam; crudam si edes, in acetum intinguito). It is a wonderful medication: as it facilitates digestion, acts as a laxative

\footnotetext{
$9 \quad$ Boscherini 1970: 63-64.
} 
(concoquit; mirifice concoquit, alvum bonam facit), and makes urine good for healing every ailment (lotiumque ad omnes res salubre est). Besides this vegetable allows eating and drinking at will during a banquet: "If you wish to drink deep at a banquet and to enjoy your dinner, eat as much raw cabbage as you wish, seasoned with vinegar, before dinner, and likewise after dinner eat some half a dozen leaves; it will make you feel as if you had not dined, and you can drink as much as you please" (Si voles in convivio multum bibere cenareque libenter, ante cenam esto crudam quantum voles ex aceto, et item, ubi cenaveris, comesto aliqua $V$ folia; reddet te quasi nihil ederis, bibesque quantum voles - Cato Agr. 156, 1).

Cato gives very specific rules for the use of cabbage in various diseases. In the first recipe he explains, how cabbage juice (mixed with salt and cumin) combined with an earlier hot bath and honey water drunk at night helps clean out the upper digestive tract. Cato recommends walking about for four hours:

Alvum si voles deicere superiorem, sumito brassicae quae levissima erit P. IIII inde facito manipulos aequales tres conligatoque. Postea ollam statuito cum aqua. Ubi occipiet fervere, paulisper demittito unum manipulum, fervere desistet. Postea ubi occipiet fervere, paulisper demittito ad modum dum quinque numeres, eximito. Item facito alterum manipulum, item tertium. Postea conicito, contundito, item eximito in linteum, exurgeto sucum quasi heminam in pocillum fictile. Eo indito salis micam quasi ervu et cumini fricti tantum quod oleat. Postea ponito pocillum in sereno noctu. Qui poturus erit, lavet calida, bibat aquam mulsam, cubet incenatus. Postea mane bibat sucum deambuletque horas IIII, agat, negoti siquid habebit. Ubi libido veniet, nausia adprehendet, decumbat purgetque sese. Tantum bilis pituitaeque eiciet, uti ipse miretur, unde tantum siet. Postea ubi deorsum versus ibit, heminam aut paulo plus bibat. Si amplius ibit, sumito farinae minutae concas duas, infriet in aquam, paulum bibat, constituet.

If you wish to clean out the upper digestive tract, take four pounds of very smooth cabbage leaves, make them into three equal bunches and tie them together. Set a pot of water on the fire, and when it begins to boil sink one bunch for a short time, which will stop the boiling; when it be- 
gins again sink the bunch briefly while you count five, and remove. Do the same with the second and third bunches, then throw the three together and macerate. After macerating, squeeze through a cloth about a hemina of the juice into an earthen cup; add a lump of salt the size of a pea, and enough crushed cummin to give it an odour, and let the cup stand in the air through a calm night. Before taking a dose of this, one should take a hot bath, drink honey-water, and go to bed fasting. Early the next morning he should drink the juice and walk about for four hours, attending to any business he has. When the desire comes on him and he is seized with nausea, he should lie down and purge himself; he will evacuate such a quantity of bile and mucus that he will wonder himself where it all came from. Afterwards, when he goes to stool, he should drink a hemina or a little more. If it acts too freely, if he will take two conchas [conchaseashell, as a unit of measure, the equivalent of a spoon] of fine flour, sprinkle it into water, and drink a little, it will cease to act (Cato Agr. 156, 2-4).

The second recipe concerns a cabbage remedy for colic (tormina). It helps adults and children: "The treatment is the same for man, woman, and child" (Ad eundem modum viro et mulieri et puero dato - Cato Agr. 156, 6). Cato gives instructions for a preparation and a medication, depending on the patient's condition:

Verum quibus tormina molesta erunt, brassicam in aqua macerare oportet. Ubi macerata erit, coicito in aquam calidam, coquito usque donec conmadebit bene, aquam defundito. Postea salem addito et cumini paululum et pollinem polentae eodem addito et oleum. Postea fervefacito, infundito in catinum, uti frigescat. Eo interito quod volet cibi, postea edit. Sed si poterit solam brassicam esse, edit. Et si sine febre erit, dato vini atri duri aquatum bibat quam minimum; si febris erit, aquam. Id facito cotidie mane. Nolito multum dare, ne pertaedescat, uti possit porro libenter esse.

Those who are suffering from colic should macerate cabbage in water, then pour into hot water, and boil until it is quite soft. Pour off 
the water, add salt, a bit of cummin, barley flour dust, and oil, and boil again; turn into a dish and allow it to cool. You may break any food you wish into it and eat it; but if you can eat the cabbage alone, do so. If the patient has no fever, administer a very little strong, dark wine, diluted; but if he has fever give only water. The dose should be repeated every morning, but in small quantities, so that it may not pall but continue to be eaten with relish (Cato Agr. 156, 5-6).

The third recipe describes how to prepare a remedy for those who pass urine with difficulty and suffer from strangury (cf. Cato Agr. 156, 7: Nunc de illis, quibus aegre lotium it quibusque substillum est): "take cabbage, place it in hot water and boil until it is half-done; pour off most of the water, add a quantity of oil, salt, and a bit of cummin, and boil for a short time. After that drink the broth of this and eat the cabbage itself, that it may be absorbed quickly. Repeat the treatment daily" (Sumito brassicam, coicito in aquam ferventem, coquito paulisper, uti subcruda siet. Postea aquam defundito non omnem. Eo addito oleum bene et salem et cumini paululum, infervefacito paulisper. Postea inde iusculum frigidum sorbere et ipsam brassicam esse, uti quam primum excoquatur. Cotidie id facito - ibidem).

Mild cabbage (lenis), which has a small stalk, is tender and the most pungent of all, and its juice has the most powerful effect: "No other variety of cabbage approaches it in medicinal value" (de omnibus brassicis nulla est illius modi medicamento - Cato Agr. 157, 2). Therefore, Cato recommends that it should be used twice a day. It can be made into a poultice, by first washing its surface in warm water and then crushing it, with the addition of barley-meal (farina hordeacea) if it is to be used on children. This cabbage can be a compress for all kinds of wounds (omnia vulnera), swellings (tumores), all sores (omnia ulcera), boils (tumida, vulnera putida) and all kinds of tumours, like black ulcer and white ulcer (canceres: cancer ater and cancer albus), ulcer on the breast and a cancer (in mammis ulceris et carcinoma), also dislocation (luxatum) and contusion (contusum). It cleanses and heals without pain (purgabit sanaque faciet sine dolore), accelerates swelling (concoquit) and opens boils (erumpit), removes all putridity (omnem putorem adimet), relieves the pain (dolores auferet - cf. Cato Agr. 157, 3-5). 
Eating cabbage is very healthy: "nothing will be more wholesome" (salubrius nihil est - Cato Agr. 157, 5), and "there is no expense involved" (nullus sumptus est-Cato Agr. 157, 8). Cato gives many recipes for dishes that regulate the functioning of the stomach, promote digestion, heal old illnesses, alleviate headache and eyeache, and can cure all the internal organs: a swollen spleen, or a painful heart, liver, lungs, or diaphragm. Chopped, washed, dried, and seasoned with salt and vinegar (possibly also with grape vinegar or salt, chopped coriander and rue), cabbage should be eaten in the morning, on an empty stomach:

Et si voles eam consectam lautam siccam sale aceto sparsam esse [...] Quo libentius edis, aceto mulso spargito; lautam siccam et rutam coriandrum sectam sale sparsam paulo libentius edes. Id bene faciet et mali nihil sinet in corpore consistere et alvum bonam faciet. Siquid antea mali intus erit, omnia sana faciet, et de capite et de oculis omnia deducet et sanum faciet. Hanc mane esse oportet ieiunum. Et si bilis atra est et si lienes turgent et si cor dolet et si iecur aut pulmones aut praecordia, uno verbo omnia sana faciet intro quae dolitabunt. Eodem silpium inradito, bonum est. Nam venae omnes ubi sufflatae sunt ex cibo, non possunt perspirare in toto corpore; inde aliqui morbus nascitur. Ubi ex multo cibo alvus non it, pro portione brassica si uteris, id ut te moneo, nihil istorum usu veniet morbis. Verum morbum articularium nulla res tam purgat, quam brassica cruda, si edes concisam et rutam et coriandrum concisam siccam et sirpicium inrasum et brassicam ex aceto oxymeli et sale sparsam.

If you eat it chopped, washed, dried, and seasoned with salt and vinegar [...]. That you may eat it with better appetite, sprinkle it with grape vinegar, and you will like a little better when washed, dried, and seasoned with rue, chopped coriander and salt. This will benefit you, allow no ill to remain in the body, and promote digestion; and will heal any ill that may be inside. Headache and eyeache it heals alike. It should be eaten in the morning, on an empty stomach. Also if you are bilious, if the spleen is swollen, if the heart is painful, or the liver, or the lungs, or the diaphragm - in a word, it will cure all the internal organs which are suffering. (If you grate silphium into it, it will be good.) For when all the veins are gorged with food they cannot breathe in the whole body, and hence 
a disease is caused; and when from excess of food the bowels do not act, if you eat cabbage proportionately, prepared as I direct above, you will have no ill effects from these. But as to disease of the joints, nothing so purges it as raw cabbage, if you eat it chopped, and rue, chopped dry coriander, grated asafetida, and cabbage out of vinegar and honey, and sprinkled with salt (Cato Agr. 157, 5-7).

The list of medicinal uses of cabbage continues:

- sleeplessness or senility (insomnis vel siquis est seniosus) - "give the person, without food, simply warm cabbage, oiled, and a little salt" (assam brassicam et unctam caldam, salis paulum dato homini ieiuno - Cato Agr. 157, 8);

- colic - "Macerate cabbage thoroughly, then put in a pot and boil well; when it is well done pour off the water, add plenty of oil, very little salt, cummin, and fine barley-flour, and let it boil very thoroughly again. After boiling turn it into a dish. The patient should eat it without bread, if possible; if not, plain bread may be soaked in it and if he has no fever he may have some dark wine" (Brassicam macerato bene, postea in aulam coicito, defervefacito bene. Ubi cocta erit bene, aquam defundito. Eo addito oleum bene et salis paululum et cuminum et pollinum polentae. Postea ferve bene facito. Ubi ferverit, in catinum indito. Dato edit, si poterit, sine pane; si non, dato panem purum ibidem madefaciat. Et si febrim non habebit, dato vinum atrum bibat - Cato Agr. 157, 9);

- debility - cabbage prepared as above cures debilitated person and "still further, if you save the urine of a person who eats cabbage habitually, heat it, and bathe the patient in it, he will be healed quickly; this remedy has been tested. Also, if babies are bathed in this urine they will never be weakly" (Et hoc amplius lotium conservato eius qui brassicam essitarit, id calfacito, eo hominem demittito, cito sanum facies hac cura; expertum hoc est. Item pueros pusillos si laves eo lotio, numquam debiles fient - Cato Agr. 157, 10);

- poor sight and head and neck pain - "those whose eyes are not very clear will see better if they are bathed in this urine; and pain in the head or neck will be relieved if the heated urine is applied" (Et quibus 
oculi parum clari sunt, eo lotio inunguito, plus videbunt. Si caput aut cervices dolent, eo lotio caldo lavit, desinent dolere - ibidem);

- diseases of female genital tract (or: irregular menstruation) - "If a woman will warm the privates with this urine, they will never become diseased. The method is as follows: when you have heated it in a pan, place under a chair whose seat has been pierced. Let the woman sit on it, cover her, and throw garments around her" (Et si mulier eo lotio locos fovebit, numquam miseri - or: umseri, or: menses seri - fient, et fovere sic oportet: ubi in scutra fervefeceris, sub sellam supponito pertusam. Eo mulier adsidat, operito, circum vestimenta eam dato - Cato Agr. 157, 11).

Furthermore, Cato describes the medicinal use of wild cabbage (brassica erratica). It helps as a purge:

Brassica erratica maximam vim habet. Eam arfacere et conterere oportet bene minutam. Siquem purgare voles, pridie ne cenet, mane ieiuno dato brassicam tritam, aquae cyatos IIII. Nulla res tam bene purgabit, neque elleborum neque scamonium, et sine periculo, et scito salubrem esse corpori. Quos diffidas sanos facere, facies. Qui hac purgatione purgatus erit, sic eum curato. Sorbitione liquida hoc per dies septem dato. Ubi esse volet, carnem assam dato. Si esse non volet, dato brassicam coctam et panem, et bibat vinum lene dilutum, lavet raro, utatur unctione. Qui sic purgatus erit, diutina valetudine utetur, neque ullus morbus veniet nisi sua culpa.

Wild cabbage has the greatest strength; it should be dried and macerated very fine. When it is used as a purge, let the patient refrain from food the previous night, and in the morning, still fasting, take macerated cabbage with four cyathi of water. Nothing will purge so well, neither hellebore, nor scammony; it is harmless, and highly beneficial; it will heal persons whom you despair of healing. The following is the method of purging by this treatment: Administer it in a liquid form for seven days; if the patient has an appetite, feed him on roast meat, or, if he has not, on boiled cabbage and bread. He should drink diluted mild wine, bathe rarely, and rub with oil. One so purged will enjoy good health for a long time, and no sickness will attack him except by his own fault (Cato Agr. 157, 12-13). 
Cabbage is an ingredient for a body purgative. It is an excellent purgative and an agreeable dish:

Alvum deicere hoc modo oportet, si vis bene tibi deicere. Sume tibi ollam, addito eo aquae sextarios sex et eo addito ungulam de perna. Si ungulam non habebis, addito de perna frustum P. S quam minime pingue. Ubi iam coctum incipit esse, eo addito brassicae coliculos duos, betae coliculos duos cum radice sua, feliculae pullum, herbae Mercurialis non multum, mitulorum L. II, piscem capitonem et scorpionem I, cochleas sex et lentis pugillum. Haec omnia de coquito usque ad sextarios III iuris. Oleum ne addideris. Indidem sume tibi sextarium unum tepidum, adde vini Coi cyatum unum, bibe, interquiesce, deinde iterum eodem modo, deinde tertium: purgabis te bene. Et si voles insuper vinum Coum mixtum bibere, licebit bibas. Ex iis tot rebus quod scriptum est unum, quod eorum vis, alvum deicere potest. Verum ea re tot res sunt, uti bene deicias, et suave est.

Recipe for a purgative, if you wish to purge thoroughly: Take a pot and pour into it six sextarii of water and add the hock of a ham, or, if you have no hock, a half-pound of ham-scraps with as little fat as possible. Just as it comes to a boil, add two cabbage leaves, two beet plants with the roots, a shoot of fern, a bit of the mercury-plant, two pounds of mussels, a capito fish and one scorpion, six snails, and a handful of lentils. Boil all together down to three sextarii of liquid, without adding oil. Take one sextarius of this while warm, add one cyathus of Coan wine, drink, and rest. Take a second and a third dose in the same way, and you will be well purged. You may drink diluted Coan wine in addition, if you wish. Any one of the many ingredients mentioned above is sufficient to move the bowels; but there are so many ingredients in this concoction that it is an excellent purgative, and, besides, it is agreeable (Cato Agr. 158, 1-2).

Brassica erratica (wild cabbage) cures a suppurated or new ulcer (ulcus taetrum vel recens): "sprinkle this wild cabbage with water and apply it" (hanc brassicam erraticam aqua spargito, opponito - Cato Agr. 157, 13). It heals a fistula: "insert a pellet; or if it will not admit a pellet, make a solution, pour into a bladder attached to a reed, and inject into the fistula by squeezing the bladder. It will heal quickly. An 
application of wild cabbage macerated with honey to any ulcer, old or new, will heal it" (turundam intro trudito. Si turundam non recipiet, diluito, indito in vesicam, eo calamum alligato, ita premito, in fistulam introeat; ea res sanum faciet cito. Et ad omnia ulcera vetera et nova contritam cum melle opponito, sanum faciet - Cato Agr. 157, 14). Wild cabbage is an aid for nasal polyps (polypus in naso intro): "pour macerated dry wild cabbage into the palm of the hand; apply to the nostril and sniff with the breath as vigorously as possible. Within three days the polypus will fall out, but continue the same treatment for several days after it has fallen out, so that the roots of the polypus may be thoroughly cleaned" (brassicam erraticam aridam tritam in manum conicito et ad nasum admoveto, ita subducito susum animam quam plurimum poteris; in triduo polypus excidet. Et ubi exciderit, tamen aliquot dies idem facito, ut radices polypi persanas facias - Cato Agr. 157, 15). This is not the end of the medicinal properties of wild cabbage. It is a remedy for hearing impairment: "In case of deafness, macerate cabbage with wine, press out the juice, and instil warm water into the ear, and you will soon know that your hearing is improved" (Auribus si parum audies, terito cum vino brassicam, sucum exprimito, in aurem intro tepidum instillato; cito te intelleges plus audire - Cato Agr. 157, 16), and for scabs: "An application of cabbage to a malignant scab will cause it to heal without ulcerating" (Depetigini spurcae brassicam opponito, sanam faciet et ulcus non faciet - ibidem). Thus, the cabbage is a wonderful medicament for many diseases.

\section{MEDICINES FOR ANIMALS}

In a number of chapters, Cato discusses medicines for animals. Most of his remarks concern oxen, one refers to sheep. The author gives a recipe for a cure for sheep scab and ticks. This remedy causes the growth of longer and better quality wool and is suitable for all quadrupeds:

Oves ne scabrae fiant. Amurcam condito, puram bene facito, aquam in qua lupinus deferverit et faecem de vino bono, inter se omnia conmisceto pariter. Postea cum detonderis, unguito totas, sinito biduum aut triduum consudent. Deinde lavito in mari; si aquam marinam non habebis, facito 
aquam salsam, ea lavito. Si haec sic feceris, neque scabrae fient et lanae plus et meliorem habebunt, et ricini non erunt molesti. Eodem in omnes quadripedes utito, si scabrae erunt.

To keep scab from sheep; Take equal parts of old strained amurca, water in which lupines have been boiled, and dregs of good wine, and mix all together. After shearing, smear the whole body with this, and let them sweat two or three days. Then wash them in the sea, or, if you have no sea-water, make a brine and wash them in it. If you do this as directed, they will not have the scab, will bear more wool and of better quality, and ticks will not bother them. Use the same remedy for all quadrupeds if they have the scab (Cato Agr. 96, 1-2; cf. Colum. De re rustica VII 4, 7-8).

Other veterinary observations refer to oxen (boves). One of them recommends tar as a means of keeping the animal's hoofs healthy: "To keep oxen from wearing down their feet, smear the bottom of their hoofs with melted pitch before you drive them anywhere on a road" (Boves ne pedes subterant, priusquam in viam quoquam ages, pice liquide cornua infima unguito - Cato Agr. 72, 1). Cato also writes about a preventive medicine suitable for healthy animals ("give the oxen before they get sick" - sanis dato), "if you have reason to fear sickness" (Si morbum metues, sanis dato - Cato Agr. 70, 1). Beside certain magical procedures to be performed, the recipe for this remedy for oxen (bubus medicamentum) includes a considerable number of ingredients: salt, laurel, leek, rocambole (Allium scordoprasum L., sand leek, called Punic garlic, allium Punicum [cf. Colum. De re rustica XI 3, 20]; a species of wild onion in the Amaryllis family, Amaryllidaceae, the garlic subfamily, Alliaceae), garlic, incense, Sabine herb, rue, bryony (Bryonia alba L., white bryony or wild hop; a vigorous vine in the family Cucurbitaceae), beans, live coals and wine (cf. ibidem). The live coals are the magical elements of this recipe.

When an ox begins to fall ill, Cato recommends: "administer at once one hen's egg raw, and make him swallow it whole. The next day macerate a head of leek with a hemina of wine, and make him drink it all" (dato continuo ei unum ovum gallinaceum crudum; integrum facito devoret. Postridie caput ulpici conterito cum hemina vini facitoque ebibat - Cato Agr. 71, 1). 
As part of his preventive medical advice, Cato also recommends that oxen should always drink good and clean water (aquam bonam et liquidam) in summer and receive medicine every year (quotannis), when the grapes begin to change colour (cf. Cato Agr. 73, 1). This medicine is made from snake skin, spelt, salt, thyme and wine: "When you see a snake skin, pick it up and put it away, so that you will not have to hunt for one when you need it. Macerate this skin, spelt, salt, and thyme with wine, and give it to all the cattle to drink" (Pellem anguinam ubi videris, tollito et condito, ne quaeras cum opus siet. Eam pellem et far et salem et serpulum, haec omnia una conterito cum vino, dato bubus bibant omnibus - ibidem). Although spelt (far adoreum) in the days of Cato was gradually losing its significance for agriculture due to its poorer taste in favor of triticum, siligo and trimestris, it still occupied a significant place among the crops of Italy. Cato writes about it far too often, namely fourteen times: once he writes about its cultivation, and then about its use and the flour and groats, received from it. ${ }^{10}$

In another chapter, Cato recommends adding amurca to fodder for oxen:

Boves uti valeant et curati bene sint, et qui fastidient cibum, uti magis cupide adpetant, pabulum quod dabis amurca spargito; primo paululum, dum consuescant, postea magis, et dato rarenter bibere conmixtam cum aqua aequabiliter. Quarto quinto quoque die hoc sic facies. Ita boves et corpore curatiores erunt, et morbus aberit.

To keep cattle well and strong, and to increase the appetite of those which are off their feed, sprinkle the feed which you give with amurca. Feed in small quantities at first to let them grow accustomed to it, and then increase. Give them less often a draught of equal parts of amurca and water. Do this every fourth or fifth day. This treatment will keep them in better condition, disease will stay away from them (Cato Agr. 103, 1).

Cato also describes a remedy for a snake bite. It is an aid for an ox or another quadruped, or a human: "When a serpent has bitten an ox

$10 \quad$ Mikołajczyk 2009: 29-30. 
or any other quadruped, macerate an acetabulum [acetabulum $=0,07$ 1] of fennel flower, which the physicians call smyrnaeum, in a hemina of old wine. Administer through the nostrils, and apply swine's dung to the wound itself. Treat a person in the same way if occasion arises" ( $\mathrm{Si}$ bovem aut aliam quamvis quadrupedem serpens momorderit, melanthi acetabulum, quod medici vocant zmurnaeum, conterito in vini veteris hemina. Id per nares indito et ad ipsum morsum stercus suillum adponito. Et idem hoc, si usus venerit, homini facito - Cato Agr. 102, 1). The melanthium seems to mean either cultivated fennel or chamomile, or veratrum, ${ }^{11}$ or black-caraway also known as nigella or black cumin ( $\mathrm{Ni}$ gella sativa L.; an annual flowering plant of the family Ranunculaceae) and to have been mistakenly identified by Cato with another anti-bite remedy, called the zmurnaeum (cf. Plin. Nat. XIX 162 and XX 177-178; Colum. De re rustica XI 3, 36).

Apart from different medicines for oxen, Cato also recommends making sacrifices to the gods to ensure good health of the animals. The author explains that the sacrifice should be submitted at the time of the flowering of the pear, before the spring plowing: "Make the offering for the oxen when the pear trees bloom; then begin the spring ploughing" (Piro florente dapem pro bubus facito. Postea verno arare incipito Cato Agr. 131, 1). He describes the specifics of the ritual twice:

Votum pro bubus, uti valeant, sic facito. Marti Silvano in silva interdius in capita singula boum votum facito. Farris L. III et lardi P. IIII S et pulpae P. IIII S, vini S. III, id in unum vas liceto coicere, et vinum item in unum vas liceto coicere. Eam rem divinam vel servus vel liber licebit faciat. Ubi res divina facta erit, statim ibidem consumito. Mulier ad eam rem divinam ne adsit neve videat quo modo fiat. Hoc votum in annos singulos, si voles, licebit vovere.

Perform the vow for the health of the cattle as follows: Make an offering to Mars Silvanus in the forest during the daytime for each head of cattle: 3 pounds of meal, $4 \frac{1}{2}$ pounds of bacon, $4 \frac{1}{2}$ pounds of meat, and 3 pints of wine. You may place the viands in one vessel, and the wine likewise in one vessel. Either a slave or a free man may make this offering. After 
the ceremony is over, consume the offering on the spot at once. A woman may not take part in this offering or see how it is performed. You may vow the vow every year if you wish (Cato $A g r .83,1$ ).

In the second fragment, Cato describes the sacrifice of wine and agricultural products for Jupiter Dapalis (this epithet of Jupiter is derived from the old Roman custom of spreading an offering of food (daps) before the spring and the autumn sowing), and for Vesta, although the latter sacrifice is not necessary:

Dapem hoc modo fieri oportet. Iovi dapali culignam vini quantam vis polluceto. Eo die feriae bubus et bubulcis et qui dapem facient. Cum pollucere oportebit, sic facies: "Iuppiter dapalis, quod tibi fieri oportet in domo familia mea culignam vini dapi, eius rei ergo macte hac illace dape pollucenda esto”. Manus interluito, postea vinum sumito: „Iuppiter dapalis, macte istace dape pollucenda esto, macte vino inferio esto". Vestae, si voles, dato. Daps Iovi assaria pecunia urna vini. Iovi caste profanato sua contagione. Postea dape facta serito milium, panicum, alium, lentim.

The offering is to be made in this way: Offer to Jupiter Dapalis a cup of wine of any size you wish, observing the day as a holiday for the oxen, the teamsters, and those who make the offering. In making the offering use this formula: "Jupiter Dapalis, forasmuch as it is fitting that a cup of wine be offered thee, in my house and in the midst of my people, for they sacred feast; and to that end, be thou honoured by the offering of this food". Wash the hands, then take the wine, and say: "Jupiter Dapalis, be thou honoured by the offering of thy feast, and be thou honoured by the wine placed before thee". You may make an offering to Vesta if you wish. Present it to Jupiter religiously, in the fitting form. The feast to Jupiter consists of roasted meat and an urn of wine. After the offering is made plant millet, panic grass, garlic, and lentils (Cato Agr. 132, 1-2 ${ }^{12}$ ).

12 Winniczuk 2006: 502-504. 


\section{MAGIC MEDICINE}

Cato adds elements of magic to some of his recipes for medicines for oxen. One of his formulas relies heavily on the repetition of the number three, requires the use of twelve ingredients and live coals, and the resulting medicine has to be administered using a wooden vessel by a person who is fasting. The entire procedure of preparing the remedy and administering it has to be performed while standing, without touching the ground:

dato salis micas tres, folia laurea III, porri fibras III, ulpici spicas III, alii spicas III, turis grana tria, herbae Sabinae plantas tres, ruta folia tria, vitis albae caules III, fabulos albos III, carbones vivos III, vini S. III. Haec omnia sublimiter legi teri darique oportet. Ieiunus siet qui dabit. Per triduum de ea potione uni cuique bovi dato. Ita dividito, cum ter uni cuique dederis, omnem absumas, bosque ipsus et qui dabit facito ut uterque sublimiter stent. Vaso ligneo dato.

give [...]: 3 grains of salt, 3 laurel leaves, 3 leek leaves, 3 spikes of leek, 3 of garlic, 3 grains of incense, 3 plants of Sabine herb, 3 leaves of rue, 3 stalks of bryony, 3 white beans, 3 live coals, and 3 pints of wine. You must gather, macerate, and administer all these while standing, and he who administers the remedy must be fasting. Administer to each ox for three days, and divide it in such a way that when you have administered three doses to each you will have used it all. See that the ox and the one who administers are both standing, and use a wooden vessel (Cato Agr. 70, 1-2).

Similar magic rules are found in another recipe, shown above: "Macerate while standing, and administer in a wooden vessel. Both the ox and the one who administers must stand, and both be fasting" (Sublimiter terat et vaso ligneo det, bosque ipsus et qui dabit sublimiter stet. Ieiunus ieiuno bovi dato - Cato Agr. 71, 1).

Towards the end of the treatise, Cato makes further two brief remarks which are magical in nature in relation to humans. First, chafing may be prevented (intertrigini remedium) if one follows the following advice: "When you set out on a journey, keep a small branch of Pontic 
wormwood under the anus" (In viam cum ibis, apsinthi Pontici surculum sub anulo habeto - Cato Agr. 159, 1). Secondly, he gives spells - these are incomprehensible words - for healing a dislocation or a fracture:

Luxum siquod est, hac cantione sanum fiet. Harundinem prende tibi viridem P. IIII aut quinque longam, mediam diffinde, et duo homines teneant ad coxendices. Incipe cantare: „motas uaeta daries dardares astataries dissunapiter", usque dum coeant. Ferrum insuper iactato. Ubi coierint et altera alteram tetigerint, id manu prehende et dextra sinistra praecide, ad luxum aut ad fracturam alliga, sanum fiet. Et tamen cotidie cantato et luxato vel hoc modo: „, huat haut haut istasis tarsis ardannabou dannaustra”.

Any kind of dislocation may be cured by the following charm: Take a green reed four or five feet [118, $4 \mathrm{~cm}$ or $148 \mathrm{~cm}$ ] long and split it down the middle, and let two men hold it to your hips. Begin to chant: "motas uaeta daries dardares astataries dissunapiter" and continue until they meet. Brandish a knife over them, and when the reeds meet so that one touches the other, grasp with the hand and cut right and left. If the pieces are applied to the dislocation or the fracture, it will heal. And none the less chant every day, and, in the case of a dislocation, in this manner, if you wish: "huat haut haut istasis tarsis ardannabou dannaustra" (Cato Agr. 160, 1).

As evident from this description, beside relying on magic Cato recommends setting up splint to immobilize a sprained joint or fracture.

\section{CONCLUSIONS}

The treatise On Agriculture provides us with many interesting information about folk medicine or natural medicine. Cato - an experienced commander, a politician, but also a landowner ${ }^{13}$, and therefore the Roman model of his epoch (a good Roman citizen was a good house

13 On the importance of agriculture in Rome cf. Hollander 2018; about Cato cf. Hollander 2018: chapter 1.3.1. 
master) - describes many ways of healing different diseases of humans and animals (especially oxen). Primarily he makes these medicines: various types of wines and dishes based on cabbage. His recommendations are detailed and appear to indicate that the author knows them well and uses them himself, probably with positive results. While Cato does not neglect the religious and magical aspects of medicine in his medical advice, they are certainly not dominant.

\section{REFERENCES}

\section{Primary sources}

Cato (Marcus Porcius Cato, Cato the Elder), 1922, De agri cultura (On Agriculture), G. Goetz (ed.), Lipsiae, transl. W.D. Hooper, H.B. Ash (Loeb Classical Library edition, 1934).

Columella (Lucius Junius Moderatus Columella), 1902-1917, De re rustica (Agriculture), V. Lundström (ed.), Uppsala.

Plinius Maior (Gaius Plinius Secundus, Pliny the Elder), 1906, Naturalis historia (Natural History), K.F.T. Mayhoff (ed.), Lipsiae.

\section{Secondary sources}

Astin A.E., 1978, Cato the Censor, Oxford.

Boscherini S., 1993, 'La medicina in Catone e Varrone', [in:] Aufstieg und Niedergang der römischen Welt II 31.1, pp. 730-740.

Boscherini S., 1970, Lingua e scienza greca nel De agri cultura di Catone, Roma.

Cytowska M., Szelest H., Rychlewska L., 1996, Literatura rzymska. Okres archaiczny, Warszawa.

Forde N.W., 1975, Cato the Censor, Boston.

Hollander D.B., 2018, Farmers and Agriculture in the Roman Economy, London, [on-line:] https://doi.org/10.4324/9781315103884.

Mezzabotta M.R., 2001, 'Ethnoveterinary Treatments in Roman Antiquity: Cato the Elder's Veterinary Remedies', Acta Classica 44, pp. 137-152.

Mikołajczyk I., 2009, 'Wstęp', [in:] Marek Porcjusz Katon, O gospodarstwie rolnym, Toruń, pp. 7-43.

Pitkäranta R., 1987, 'Der Kohl als Heilmittel. Marcus Porcius Cato (234-149 v. Chr.) und seine medizinischen Anweisungen im Werk De agricultura, 156160', Hippokrates 4, pp. 31-45. 
De Saint-Denis E., 1980, 'Eloge du Chou', Latomus 39, pp. 838-849.

Winniczuk L., 2006, Ludzie, zwyczaje i obyczaje starożytnej Grecji i Rzymu, Warszawa.

Zomlefer W.B., Judd W.S., Gandhi K.N., 2010, 'Proposal to Conserve the Name Veratrum against Melanthium (Melanthiaceae)', Taxon 59(2), pp. 644-645, [on-line:] https://doi.org/10.1002/tax.592034. 